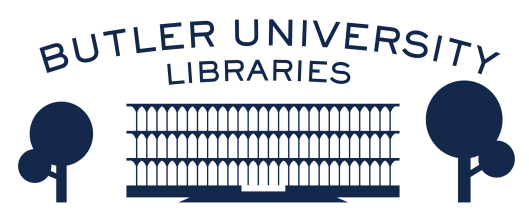

Journal of Hindu-Christian Studies

Volume 23

Article 5

January 2010

\title{
Some Recent Developments in Hindu Understandings of Jesus
}

Bradley Malkovsky

Follow this and additional works at: https://digitalcommons.butler.edu/jhcs

Part of the Religion Commons

\section{Recommended Citation}

Malkovsky, Bradley (2010) "Some Recent Developments in Hindu Understandings of Jesus," Journal of Hindu-Christian Studies: Vol. 23, Article 5.

Available at: https://doi.org/10.7825/2164-6279.1457

The Journal of Hindu-Christian Studies is a publication of the Society for Hindu-Christian Studies. The digital version is made available by Digital Commons @ Butler University. For questions about the Journal or the Society, please contact cbauman@butler.edu. For more information about Digital Commons @ Butler University, please contact digitalscholarship@butler.edu. 


\title{
Some Recent Developments in Hindu Understandings of Jesus ${ }^{1}$
}

\author{
Bradley Malkovsky \\ University of Notre Dame
}

HINDU reflection on the person and work of Jesus Christ, what we might call "Hindu christology," is an enterprise that has slowly evolved since the early nineteenth century and is still very much in the making. It has undergone some significant changes since the middle of the twentieth century with some surprising additional perspectives emerging in recent years.

\section{Classical Hindu Christology}

Most of the literature on Hindu christology, though extensive, has tended to focus on the views of such well-known philosophers, saints, and social reformers as Ram Mohan Roy (17721833), Keshub Chunder Sen (1838-1884), Sri Ramakrishna Paramahamsa (1836-1886), Swami Vivekananda (1863-1902), Mahatma Gandhi (1869-1948), and Sarvepalli Radhakrishnan (1888-1975). ${ }^{2}$ What is first of all striking about these understandings of Jesus when they are viewed collectively is the overall unanimity in regarding Jesus in a very positive way, as an inspiring, saintly, and even divine figure. ${ }^{3}$ What is equally striking are the variant, even contradictory, ways in which the significance of Jesus and the value of certain events connected to him have been articulated by these very same individuals.

Roy, for example, denies the incarnation of Jesus, although he sees Jesus" as the ideal or exemplary human being, whereas Sen, Ramakrishna and Radhakrishnan profess Jesus to be an authentic avatar or divine embodiment. For those who accept Jesus' avatarhood the precise manner in which his divinity is understood also varies greatly. Sen takes it to mean that Jesus is a divine descent from 'above' into a creaturely form, whereas Radhakrishnan sees avatarhood as the realization 'or ripening from 'below' of an innate divine potentiality that is available to all human beings. In addition, some of these figures, for example Roy and Sen, accept the death of Jesus as a real historical event, whereas Gandhiji and Radhakrishnan do not. Moreover, while all of the aforementioned persons look to Jesus' courageous and selfsacrificing life as a source of inspiration Gandhiji dismisses the necessity of Jesus' historical existence altogether in light of the more important Sermon on the Mount. He writes, "I must say that I have never been interested in a historical Jesus. I should not care if it was proved by someone that the man called Jesus never lived, and that what was narrated in the Gospels was a figment of the writer's imagination. For the Sermon on the Mount would still be true to me."

Regardless of these differences it is clear that Jesus' life in service to others, his renunciation of family life for the sake of God, his radical teaching of divine love, his fellowship with the poor and marginalized of society, and his example of patient suffering have endeared him to countless Hindus over the ages. But what also tends to unite Hindus in their view of Jesus is to consider him just one of many divine embodiments; they consequently reject the Christian claim of Jesus being the sole universal savior. And where his death is

Bradley Malkovsky teaches comparative theology at the University of Notre Dame in Indiana, U.S.A. He has two degrees in Catholic Theology from the University of Tübingen, Germany. His books include the edited New Perspectives on Advaita Vedanta: Commemoration Volume for Richard De Smet, S.J. (2000) and The Role of Divine Grace in the Soteriology of Samkara (2001), both published by Brill. 
accepted as real it is never interpreted in the Christian sense as an atonement for the sins of others.

Many of these features of what might be called classical Hindu christology continue to live on in contemporary understandings of Jesus. There is thus much continuity between old and new Hindu christologies. In what follows I present some examples of new developments and approaches to understanding the person and work of Christ. Instead of striving for completeness I restrict myself to listing a few of the more significant new perspectives and claims that are being made. Any attempt at summarizing contemporary Hindu christology must be necessarily incomplete, not only because the Hindu encounter with Christ is ongoing and dynamic, but also because it is underresearched. ${ }^{5}$ The focus here will be more on ideas, theological method, and growing tendencies and less on summarizing the writings and work of individual Hindu thinkers.

Recent Themes in Hindu Views of Christ

1. Jesus in India. ${ }^{6}$ It is sometimes stated that Jesus visited India either during" his "missing years," i.e. roughly during the ages of 12 to 30 , a period of Jesus' life about which the New Testament is silent, or after his persecution, when he escaped death, or both. ${ }^{7}$. Though this claim was never asserted among the standard nineteenth and twentieth century Hindu interpreters of Christ I have summarized, it is often stated as fact today. In the words of one Christian theologian and longtime missionary to India, there exists a

widespread popular belief that Jesus visited India in the so-called 'hidden years' before

he began his public ministry, and that he sat at the feet of some Hindu saint from whom he derived his teaching... . On the cross he did not die but merely_swooned, and then set off for the East . . Implicit in this story is the claim that Christians have misunderstood Jesus. ${ }^{8}$
The implication is that it was in India that Jesus was first indoctrinated into teachings about the non-duality of God and our inner Self. $\mathrm{He}$ then returns to Palestine with a radical new teaching about the Kingdom of God being "within" us. Christians, it is often said by advocates of this story, have never truly understood that Jesus' proclamation of the Kingdom of God was an essentially mystical message, addressed to helping us uncover our inner divine identity. To truly understand Jesus, then, according to this story, it is necessary to see that the source of his wisdom lies in the religions of India.

This assertion is repeated by such famous Hindu swamis as Paramahansa Yogananda. ${ }^{9}$ Bharat similarly refers to a "well-established Hindu belief" that Jesus lived in India during the missing, years not reported in the New Testament, that he there learned the basic teachings and practices of Yoga and Vedanta, somehow survived the crucifixion in Palestine through the use of - special yogic powers, returned to India, where he then died, and that his shrine is located in Kashmir, where it is visited by Hindus and Sufis today. ${ }^{10}$

The person who first propagated the story of Jesus traveling to India was a Russian journalist named Nicholas Notovitch. He claimed to have seen two Tibetan scrolls in 1887 in the library of the Hemis monastery in Ladakh, high up in the Himalayas, while he was recuperating from a broken leg. The library scrolls, he claimed; were in effect an unknown Gospel describing Jesus' missing years in India and Tibet, the two places where he absorbed the wisdom of Buddhism, Hinduism, and Jainism before returning home to Galilee. The original title of this gospel was "Life of Saint Issa, Best of the Sons of Men." Notovitch published the book in French in 1894 under the title $\mathrm{La}$ Vie inconnue de Jesus-Christ (The Hidden Life of Jesus Christ). It was subsequently translated into English, Italian, German, and Spanish. The book was an instant sensation in Europe and went through eight printings in France its first year.

Notovitch's claims were immediately received with skepticism by scholars who set out to check their authenticity. Foremost among these was the famous German indologist Max 
Mueller, who wrote to the chief lama at Hemis monastery about Notovitch and received the reply that no Westerner had visited there in the past fifteen years nor was the monastery in possession of any documents having anything to do with the story Notovitch had made public in his famous book. At around the same time, also in response to Notovitch, a British professor teaching in Agra named J. Archibald Douglas took it upon himself to actually make the arduous journey to the Hemis monastery to conduct a personal interview with the same head monk with whom Mueller had corresponded. What Douglas learned there completely concurred with what Mueller had learned: Notovitch had never been there, and there were no documents in the monastery about any Issa (Jesus). ${ }^{11}$

Despite the successful investigative work done by Mueller and Archibald to debunk the Notovitch hoax the story that Jesus visited India has, in the intervening decades, taken on a life of its own, even spawning a number of competing versions to the original narrative. One finds many of them on the internet today.

In none of these accounts, starting with Notovitch, whether they are propagated by Hindus or promulgated by Muslims, do we find anything like standard Christian teaching that Jesus actually did in fact die on the cross or that his death was some kind of sacrifice for humanity or that he was afterwards raised from the dead by God and transformed into a glorious transcendent state that Christians call the resurrection.

2. Many resurrections. While the resurrection of Jesus continues to be of little interest to most Hindus it is no longer always ignored or dismissed. Indeed, the resurrection of Christ is taken by some Hindus now as historical fact. But unlike the traditional Christian claim that Jesus alone has been resurrected from the dead some Hindus now assert that Jesus' resurrection is not unique. The claim is made that some of Hinduism's greatest sages and yogis have returned from the dead and appeared to their disciples or have even raised the dead themselves. ${ }^{12}$ Sri Ramakrishna is supposed to have appeared to his disciples after his death, and Swami Yogananda, in chapter forty-three of his Autobiography of a Yoga, relates to the reader his direct experience with his resurrected guru, Sri Yukteswar. ${ }^{13}$

It is important to note, in addition, that the Hindu understanding of the resurrection event and the resurrection body is very different from that of mainstream Christian faith and theology. For one, there is no talk that the resurrection of Hindu sages and saints is the work of a personal God or Absolute; the deceased sage simply reappears after the death of the body, and there is no reference to a rescue or transformation or a post-mortem appearance caused by the Supreme. The implication to be drawn is that the realized sage is himself the master over life and death.

Further, resurrection in this Hindu understanding is not the transformation of the whole human person as it is in Christian thought, but rather the visible return of the master as spirit or in the form of a "subtle" body. In summarizing the thought of Swami Satprakashananda (1888-1979) on resurrection as presented in his book, Jesus Christ and His Teachings in the Light of Vedanta, ${ }^{14}$ Bharat remarks, "For Swamiji, resurrection and eternal life do not depend on bodies as spirit is our true nature." $" 15$ More recently, Deepak Chopra has offered a dualistic understanding of Jesus' resurrection when he summarizes the Easter event as meaning that "a flesh-and-blood man was transformed into completely divine substance - the Holy Spirit."." He does not contrast his conception with more holistic Christian understandings.

Finally, it is evident that Hindu resurrections never figure prominently in Hindu soteriologies. While the faith and hope of most Christians is founded in large part on the facticity of Jesus' resúrrection, in Hindu soteriology the role of resurrection - whether that of Jesus or of any other holy figure - is finally quite insignificant. And by virtue of the fact that Hindu resurrection talk has emerged only in very recent times, one gets the impression that this particular teaching is merely a late and rather unimportant appendage grafted on to the main body of Hindu doctrine. Whether or not Jesus was resurrected, whether in fact Sri Yukteswar returned from the dead is, ultimately speaking, not of great importance for Hindus. Such post-mortem 
appearances may be a sign of the greatness, authority and power of these two spiritual masters, but in the Hindu framework the appearances do not significantly alter the contours of Hindu hope for perfection or what constitutes spiritual liberation. The Hindu expectation for liberation continues to mean, for the most part, and with few exceptions, liberation from all bodiliness. It lacks anything akin to the Jewish eschatological context in which the resurrection of Jesus derived its original meaning. Resurrection appearances for Yogananda are not a sign of the completion and integration of the whole human person, body and soul, into the divine life. The body is not given the same importance in Hindu thought as it receives in Christian faith.

3. Making Use of Uncertainties in Christian Biblical Exegesis. The identity of the Christian faith, as it has been generally understood through the ages, stands or falls on the historicity of its founder and the basic profile of his person and work as presented in the New Testament. But it is well known that some of the best Christian biblical exegetes today often disagree on the most basic facts about the life and teachings of Jesus. Those Hindus who today assert the essential Hinduness of Christ's teaching are often enough aware of the problems and uncertainties surrounding modern Christian historical and exegetical research. They believe that such uncertainties in Christian biblical scholarship open the door for them to offer their own interpretation. Since even Christian biblical exegetes cannot seem to agree on the essential nature of Christ and his mission the possibility emerges, they contend, that new Hindu interpretations of Jesus should now be regarded as as valid as traditional Christian ones. Sita Ram Goel (1921-2003), one of modern India's most vociferous critics of Christianity, drew the conclusion after having studied the Gospels and modern biblical exegesis that the evidence for Jesus' historical existence and the content of his life was scant indeed, as they are confined to New Testament documents of faith. Thus the uncertainties of Christian biblical exegesis appear to allow the possibility of accepting the legitimacy of Hindu interpretations of Jesus.
4. Reevaluating Hindu Presuppositions. In marked contrast to the above three developments, one finds today a number of Hindu scholars who do not shy away from critiquing fellow Hindus for interpreting Jesus exclusively through pre-given Hindu categories and assumptions. Such an approach makes a growth of knowledge all but impossible. Anantanand Rambachan writes:

As a Hindu, one has to resist the inclination to see and interpret Jesus in the categories of Hinduism. This approach was very common in the nineteenth and early twentieth centuries and it is not unusual today. The attempt is often made to see his life and teachings in the categories of the Hindu tradition of advaita (non- dualism). This, however, is only possible through a very selective use of the records of his sayings, and the dismissal of the way in which he has been traditionally understood by most Christians. It is an approach which claims to place little importance on dogma and doctrine, and, therefore, dismisses the significance of differences in this sphere. In reality, however, such differences must be acknowledged. Dismissing them in sweeping generalizations does not contribute much to the process of mutual understanding. ${ }^{17}$

K. R. Sundararajan expresses very similar views about the traditional Hindu appropriation of Jesus into Hindu categories, an attitude which is not sufficiently respectful of differences. One of the constant temptations we face as members of different religions is in thinking that we have nothing of significance to learn from each other, that our religion has everything. "In the present mind-set of the Hindus, the tradition has everything one needs and there is nothing to learn from 'others.' I personally feel that the sound basis for inter-religious dialogue goes beyond mere curiosity, and should be motivated by what I describe as 'the existential need' to learn from others and be conceptually broadened and spiritually benefited." 18 Sundararajan finds legitimacy in both Hindu and Christian teachings about Christ. He says that "In some 
ways Hindus cannot avoid 'Hinduizing' Jesus if they want to understand/appropriate him." But he also calls for "the expansion of and a deepening of one's own understanding of 'being religious." "19 In particular, Sundararajan suggests the need to move beyond docetic understandings of Christ and to consider the "possibility of a 'suffering God.",20

The theme is taken up by another Hindu scholar residing in the West, Chakravarthi RamPrasad. Rather than simply subsuming Jesus into the avatar pantheon as just one more example of a divine embodiment, he suggests that Jesus, while not superior to other divine manifestations, may be regarded "as being for many the most spiritually apt and emotionally satisfying and ethically fulfilling manifestation of divinity. This is not, of course, the Christian view of Jesus. But neither is it simply a Hindu reduction of Jesus to some subordinate role in a Hindu schema." 21 This approach, he feels, safeguards "what is Christian about belief in Jesus - his uniqueness - while recognizing the possibility of legitimate Hindu views of Jesus.",22

\section{Final Remarks}

In the encounter with people of other religions we are not being challenged to leave our convictions behind. Instead we should learn to be aware of how our prior views sometimes prevent us from understanding the teachings of other religions. We might then learn to be more attentive to our partners in dialogue. And although those of us who are Christian may disagree at times with the interpretations of Jesus given him by followers of other religions, such views can also broaden the perspective and context of our search to understand Jesus more fully. We might expand our awareness of the meaning and significance of Jesus through our exposure to the insights and questions of other religions.

In light of this discussion certain questions remain that might be significant for further theological inter-religious exploration of the meaning of Jesus. Should Christians, for example, rule out the possibility that Christ has appeared to Hindus and communicated with them? And are there then possibly many different experiences and legitimate interpretations of Christ? And, finally, even though the body is not given the same importance in Hindu thought as it is given in Christian theology it is also true that one of the things that the followers of both religions share is the desire to transcend the limitations of the earthly body. Can we Hindus and Christians perhaps then learn to reflect together, not only on Christ, but also on the mystery of Self, body, identity, even resurrection in light of our very different experiences of liberation in the Divine.

\section{Notes}

${ }^{1}$ For some of what follows see Bradley Malkovsky, "Christ in Hinduism: Traditional Views and Recent Developments," Alternative Christs. Ed. Olav Hammer. Cambridge University Press, 2009, pp. 150-169.

2 Especially useful are Ronald Neufeldt, "Hindu Views of Christ," in Harold Coward (ed.), HinduChristian Dialogue: Perspectives and Encounters (Maryknoll, New York: Orbis, 1989), pp. 162-175, and Jacques Dupuis, Jesus Christ at the Encounter of World Religions (Maryknoll: Orbis, 1991), pp. 1545.

${ }^{3}$ By contrast Swami Dayananda Saraswati (18241883) regarded Jesus as immoral and unspiritual.

${ }^{4}$ Mohandas K. Gandhi, The Message of Jesus Christ (Bombay: Bharatiya Vidya Bhavan, 1964), p. 37.

${ }^{5}$ But a very helpful summary of contemporary views - along with classical ones - has recently appeared in Sandy Bharat, Christ Across the Ganges: Hindu Responses to Jesus (Winchester, UK and Washington, USA: O Books, 2007). The author assesses the positions of Hindus living both in India and the West and presents important new material based in part on first-hand interviews.

${ }^{6}$ Some of the material for this section is drawn from my Gifts of Love Divine and Human: Learning from Hindus, Meditating with Buddhists, and Falling in Love with Islam (New York: HarperOne, forthcoming).

${ }^{7}$ Similar claims are found in the Islamic Ahmadiyya movement and among contemporary western authors.

${ }^{8}$ Roger Hardham Hooker, Themes in Hinduism and Christianity (Frankfurt \& New York: Peter Lang, 1989), pp. 358-359.

${ }^{9}$ Paramahansa Yogananda, Man's Eternal Quest (Los Angeles: Self-Realization Fellowship, 1945), p. 285. That Jesus lived in India was also accepted by Swami Sivananda (1887-1963). Cf. Bharat, Christ Across the Ganges, p. 41. 
${ }^{10}$ Bharat, Christ Across the Ganges, p. 6 n. 4. Diana Eck, Encountering God (Boston: Beacon Press, 1993), pp. 113-114, in her chapter comparing Christ's incarnation with Hindu avatar teaching, gives an account of her visit to the tomb in Kashmir. There Jesus is known as Yuz Asaf, "son of Joseph."

${ }^{11}$ Articles written by Mueller and Archibald on their Notovitch investigations were published in 18941896 in The Nineteenth Century magazine and can be found under "Some Articles on Notovitch, The Unknown Life of . Christ" at WWW tertullian.org/rpease/scanned/notovitch.htm.

See also George Gispert-Sauch, "Brahmabandhab Upadhyay on Notovitch," Vidyajyoti 71/8 (2007):624-625.

12 The followers of Bhagavan Shri Satya Sai Baba (1926- ) claim that he has demonstrated his omnipotence by causing the resurrection of others. Cf. Norris W. Palmer, "Baba's World: A Global Guru and His Movement," in Thomas A. Forsthoeffel and Cynthia Ann Humes (eds.), Gurus in America (Albany: SUNY Press, 2005), p. 103.

13 Paramahansa Yogananda, Autobiography of a Yogi. Los Angeles: Self-Realization Fellowship, 1998. Chapter "43, "The Resurrection of Sri Yukteswar," pp. 352ff.

${ }^{14}$ Vedanta Society of St. Louis, 1975.

${ }^{15}$ Bharat, Christ Across the Ganges, p. 61. Similarly, many years ago I heard Dr. Usharbudh Arya, now Swami Veda Bharati, at the Meditation Center in Minneapolis publicly refer to the resurrection appearances of Jesus as the encounter of the disciples with their "disembodied master."

${ }^{16}$ Deepak Chopra, The Third Jesus: The Christ We Cannot Ignore (New York: Harmony Books, 2008), 136. Chopra is by birth half-Hindu and half-Sikh. While he does not count himself as a member of any religion today, his main teachings are recognizably Hindu.

${ }_{17}$ Anantand Rambachan, The Hindu Vision (Delhi: Motilal Banarsidass, 1994), p. 45.

18 In Bharat, Christ Across the Ganges, p. 180. Sundarajan's statement was part of a response to a questionnaire sent to him and other Hindus by Bharat.

${ }^{19}$ Cited in Bharat, Christ Across the Ganges, p. 117.

${ }^{20}$ Bharat, Christ Across the Ganges, p. 181. Cf. also ibid., p. 179.

${ }^{21}$ Ram-Prasad, "Hindu Views of Jesus," in Gregory A. Barker (ed.), Jesus in the World's Faiths (Maryknoll: Orbis, 2005), p. 91. In similar fashion Rambachan lauds Jesus" "practical spirituality." "The dimension of Jesus' character to which I am referring is his outstanding demonstration of what genuine spirituality means in the process of actually living in the world. I think that he has provided some of the most concrete and finest examples of practical spirituality, or what the spiritual life means when it is translated into human relationships. In his life he has given us some of the fullest instances of the fruits of the spiritual life in action. I find no difficulty, as a Hindu, in deriving guidance and inspiration from these. . . I find that Jesus' emphasis on a living spirituality which informs and pervades all our relationships and even our smallest actions to be very meaningful. . . At the same time, I think that there is a need for contemporary Hinduism to seek more urgently to gather and emphasize the practical implications in society of its profound philosophical views about the nature of ultimate reality." Rambachan, The Hindu Vision, pp. 42-44.

${ }^{22}$ Ram-Prasad, "Hindu Views," p. 90. 